\title{
Ocena odporności na korozję wysokotemperaturową złączy spawanych laserowo rur ożebrowanych wykonanych ze stopów niklu
}

\author{
Evaluation of high-temperature corrosion resistance of laser \\ welded joints of finned tubes made of nickel alloys.
}

\section{Streszczenie}

Konieczność podnoszenia wydajności bloków energetycznych podyktowana jest zaostrzeniem przepisów przez Unię Europejską, dotyczących ograniczenia emisji $\mathrm{CO}_{2}$ do atmosfery. Wraz z podniesieniem ciśnienia i temperatury zaistniała potrzeba zastąpienia konwencjonalnych materiałów nowymi. na m. in. wymienniki ciepła zbudowane z rur ożebrowanych. Materiałami takimi są nadstopy niklu typu Inconel.

W artykule przedstawiono wyniki badań odporności na korozję wysokotemperaturową złączy spawanych laserowo rur ożebrowanych wykonanych ze stopów niklu Inconel 600 oraz 625 . Złącza poddano działaniu gazów symulujących spaliny w temperaturze $800{ }^{\circ} \mathrm{C}$. Badania odporności na korozję przeprowadzono w czasie do 1000 godzin, wykonując pomiary przyrostu masy produktów korozji co 250 godzin. Dodatkowo wykonano badania metalograficzne - obserwacja na elektronowym mikroskopie skaningowym. W celu identyfikacji produktów korozji wykonano mikroanalizę składu chemicznego EDS oraz identyfikację składu fazowego metodą XRD.

W trakcie badania ujawniono występowanie szczelnej warstwy zgorzeliny składającej się w większości z tlenku chromu. Wszystkie badane złącza charakteryzowały się wysoką odpornością na korozje wysokotemperaturową.

Słowa kluczowe: rury ożebrowane, nadstopy, korozja wysokotemperaturowa, złącza spawane, stopy nikli

\section{Abstract}

The necessity of improving the efficiency of power units is dictated by the tightening of regulations by the European Union regarding the reduction of $\mathrm{CO}_{2}$ emissions into the atmosphere. Increasing of pressure and temperaturę eventuate in need for the replacement of conventional materials with new ones. inter alia for heat exchangers constructed with finned tubes. One of the most up and comming materials are Inconel nickel superalloys.

This article presents results of research on high-temperature corrosion resistance laser-welded joints of finned tubes made of nickel alloy Inconel 600 and 625 . Welded joints subjected to influence of simulated exhaust gas at a temperature of $800{ }^{\circ} \mathrm{C}$. Weight gain measurements of corrosion products executed every 250 hours. Additionally, executed a metallographic observation on scanning electron microscope in order to identified the corrosion products made microanalysis of chemical composition EDS and identification phase composition by XRD.

Tight layer of scale covering examined finned tubes mostly consisted of chromium oxide. All examined welded-joints characterized by high resistance to high-temperature corrosion.

Keywords: finned tubes, superalloys, high-temperature corrosion, welded joints, nickel superalloys

\section{Wstęp}

Ciągły wzrostu zapotrzebowania na energię elektryczną powoduje wzrost ilość produkowanej energii, a tym samym substancji szkodliwych emitowanych do środowiska.

W celu ochrony, zarówno środowiska jak i zdrowia ludzkiego Unia Europejska wprowadza coraz to bardziej rygorystyczne normy emisji spalin. Jedynym rozwiązaniem pozwalającym jednocześnie zwiększyć wydajność bloków energetycznych oraz ograniczyć emisję szkodliwych spalin jest podniesienie parametrów ciśnienia oraz temperatury pary [1].

Współczesne bloki o parametrach nadkrytycznych charakteryzują się temperaturą pary świeżej na poziomie 600-630 ${ }^{\circ} \mathrm{C}$ przy ciśnieniu 25-30 MPa oraz temperaturą pary przegrzanej $610-630{ }^{\circ} \mathrm{C}[2,3]$. Sprawność takich bloków szacuje się na poziomie 45-46\%. Konieczność zwiększania sprawności bloków do ponad $50 \%$ wymaga podniesienia

Dr hab. inż. Janusz Adamiec, prof. nzw. PŚl; inż. Maciej Januszkiewicz - Politechnika Śląska. 
parametrów na poziom ultranadkrytyczny, tj. do temperatura pary świeżej $720^{\circ} \mathrm{C}$ przy ciśnieniu 35MPa [3]. Tego typu bloki wymagają zastosowania nowych materiałów, np. stopów niklu. W kotłach parowo-gazowych oraz w instalacjach przemysłowych dla zwiększenia sprawności cieplnej wymienników stosuje się rury ożebrowane. Rury ożebrowane wydajnie zwiększają powierzchnię wymiany ciepłą (ok. trzykrotnie w stosunku do rur gładkich) podnosząc tym samym sprawność cieplną wymiennika. Analiza danych literaturowych wskazuję, że głównym czynnikiem decydującym o sprawności cieplnej rur ożebrowanych jest ciągłość spoiny (połączenia rura-żebro) oraz stopień wtopienia spoiny. Nieciągłość spoiny na $50 \%$ długości żebra powoduje obniżenia sprawności cieplnej o prawie $20 \%$ [4]. Brak przetopienia lub niepełne przetopienie spoiny decyduje również o odporności połączenia na korozję wysokotemperaturową $w$ atmosferze spalin. W literaturze brak jest jednak danych na temat odporności na korozję wysokotemperaturową rur ożebrowanych stosowanych w wymiennikach ciepła dla energetyki. W związku z tym niezbędne jest prowadzenie badań nad odpornością na korozję wysokotemperaturową złącz w rurach ożebrowanych, spawanych laserowo wykonanych z materiałów o dużym potencjale zastosowania w blokach na parametry nadkrytyczne i ultranadkrytyczne, tj. z nadstopów niklu.

\section{Cel i zakres badań}

Celem pracy była ocena odporności na korozję wysokotemperaturową złączy rura -żebro wykonanych ze stopów niklu Inconel 600 i Inconel 625. Badania prowadzono na rurach ożebrowanych spawanych laserowo w Centrum Innowacyjnych Technologii Laserowych Energoinstal SA. Zakres pracy obejmował wykonanie badań odporności na korozję wysokotemperaturową w atmosferze symulowanych gazów spalinowych o składzie chemicznym: $0,2 \% \mathrm{HCl}, 0,08 \% \mathrm{SO}_{2}$, $9,0 \% \mathrm{O}_{2}$ oraz $\mathrm{N}_{2}$ w temperaturze $800{ }^{\circ} \mathrm{C}$ przez 1000 godzin.

\section{Metodyka i wyniki badań}

Badania odporności na korozję wysokotemperaturową złącza rura - żebro w atmosferze symulowanych spalin zostały wykonane w Instytucie Nauki o Materiałach Wydziału Inżynierii Materiałowej i Metalurgii w Katowicach. Schemat stanowiska badawczego zbudowanego z pieców rurowych z zabudowanymi rurami kwarcowymi i ceramicznymi, reduktorów, punktów poboru gazu z rotametrami, układu neutralizującego oraz butli z gazami wchodzącymi w skład symulowanej mieszaniny gazów pokazano na rysunku 1 . Jako miarę odporności na korozję wysokotemperaturową rur ożebrowanych przyjęto zmianę masy próbki po badaniach.
Do badań wycięto próbki złączy rura-żebro spawanych laserowo spoiną pod żebro. Szerokość próbki obejmowała trzy żebra. Tak przygotowane próbki umieszczono w tygielkach badawczych z $\mathrm{Al}_{2} \mathrm{O}_{3}$ i zamocowano w komorze badawczej pieca rurowego. Jako mieszaninę gazów testowych stosowano mieszankę o składzie $\mathrm{N}_{2}+9 \% \mathrm{O}_{2}+0,08 \% \mathrm{SO}_{2}+0,2 \% \mathrm{HCl}$, której skład odpowiada typowym spalinom w kotłach odzysknicowych w układach suchego chłodzenia koksu - CDQ. Badania odporności na korozję wysokotemperaturową złączy spawanych przeprowadzono w temperaturze $800{ }^{\circ} \mathrm{C}$. Procedura eksperymentu została podzielona na trzy etapy:

- nagrzewanie wsadu pieca w atmosferze argonu, aż do zadanej temperatury $\left(800^{\circ} \mathrm{C}\right)$,

- w celu uniknięcia procesu utleniania próbek;

- wytrzymanie próbek w atmosferze korozyjnej o zadanych stężeniach gazów przy zadanej temperaturze i przepływie mieszaniny gazów zapewniającym jednokrotną wymianę atmosfery w czasie czterech godzin;

- chłodzenie wsadu pieca w atmosferze argonu, aż do temperatury $20^{\circ} \mathrm{C}$.

Badania odporności na korozję przeprowadzono w czasie do 1000 godzin, wykonując pomiary przyrostu masy produktów korozji co 250 godzin. Dla każdej z próbek wykonywano po trzy pomiary masy, które zostały uśrednione. Odchylenie standardowe od średniej było poniżej 1\%. Przykładowe krzywe opisujące zmianę masy w czasie dla rur ożebrowanych ze stopu Inconel 600 i Inconel 625 pokazano na rysunku 2.

Uzupełnieniem badań odporności złączy spawanych rura-żebro na korozję wysokotemperaturową były badania metalograficzne. Przykładowe próbki po badaniach korozyjnych oraz powierzchnię złącza obserwowaną na elektronowym mikroskopie skaningowym (SEM) pokazano na rysunku 3. W celu identyfikacji produktów korozji wykonano mikroanalizę składu chemicznego EDS oraz identyfikację składu fazowego metodą XRD. Wyniki pokazano odpowiednio na rysunkach $4 \div 5$.

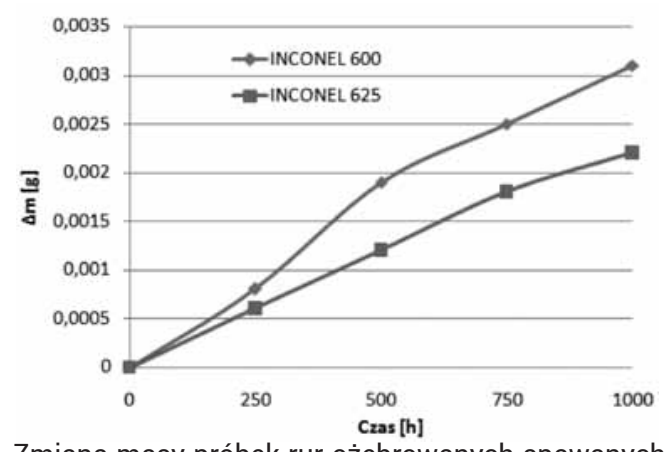

Rys. 2. Zmiana masy próbek rur ożebrowanych spawanych laserowo spoiną pod żebro ze stopów Inconel 600 i Inconel 625

Fig. 2. The mass change of the laser-welded finned tubes made of alloy Inconel 600 and Inconel 625

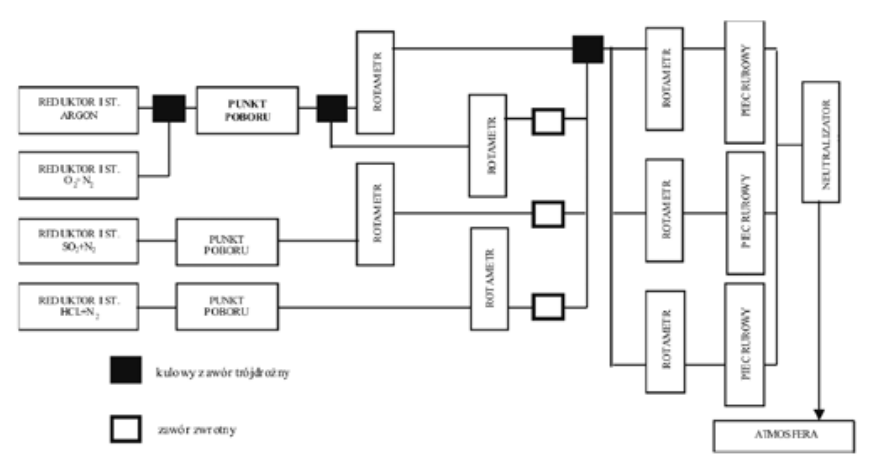

Rys. 1. Schemat stanowiska do badań korozji wysokotemperaturowej rur ożebrowanych

Fig. 1. The scheme of the high-temperature corrosion tests post 

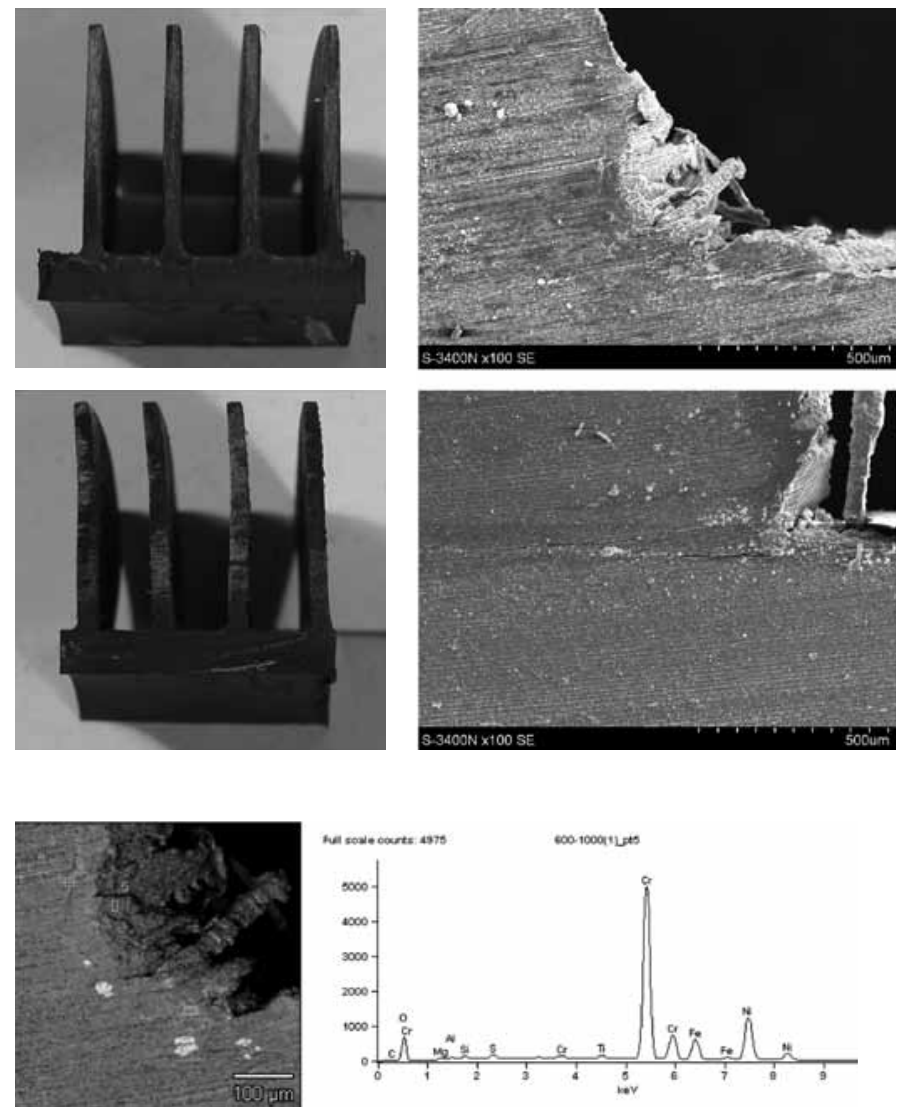

Counts

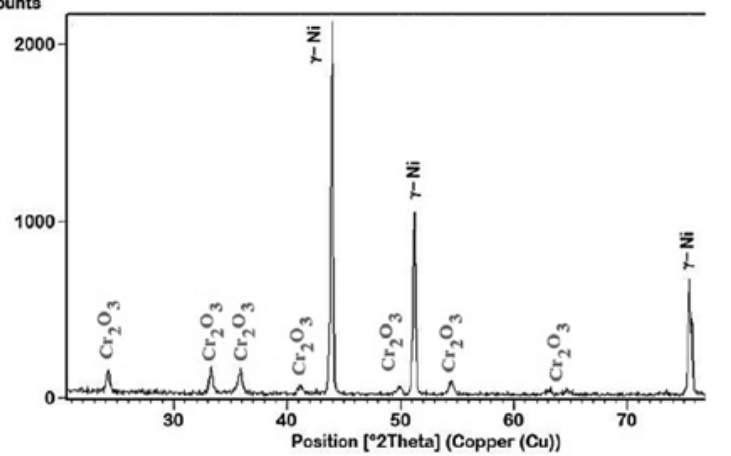

Rys. 4. Wyniki badań produktów korozji rur ożebrowanych ze stopu Inconel 600: a) powierzchnia próbki z warstwą produktów korozji, b) wyniki mikroanalizy składu chemicznego (EDS), c) wyniki analizy składu chemicznego produktów korozji

Fig. 4. The results of the finned tubes corrosion products examination of Inconel $600:$ a) the sample surface with a layer of corrosion products $b$ ) the results of chemical composition microanalysis (EDS), c) the results of analysis of chemical composition of the corrosion products
Rys. 3. Powierzchnia próbek wyciętych z rur ożebrowanych ze stopów niklu spawanych laserowo po badaniach odporności na korozję wysokotemperaturową w atmosferze gazów spalinowych przez 1000 godzin w temperaturze $800^{\circ} \mathrm{C}$ : a) powierzchnia próbki ze stopu Inconel 600, b) produkty korozji w obszarze grani spoiny stopu Inconel 600, c) powierzchni próbki ze stopu Inconel 625, d) równomiernie rozłożone produkty korozji na powierzchni próbki ze stopu Inconel $625 \mathrm{z}$ widocznymi pęknięciami

Fig. 3. The surface of samples cut from the laser welded finned tubes made of nickel alloys after high-temperature corrosion tests in the atmosphere of the exhaust gas for 1000 hours at $800^{\circ} \mathrm{C}$ Nat: a) the surface of the sample Inconel $600, \mathrm{~b}$ ) the corrosion products in the area of the weld root Inconel $600, c$ ) of the sample surface Inconel 625, d) uniformly distributed corrosion products on the surface of the sample Inconel 625 with visible cracks
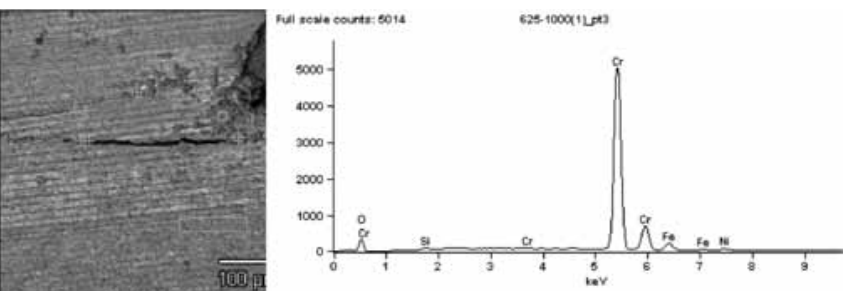

Counts

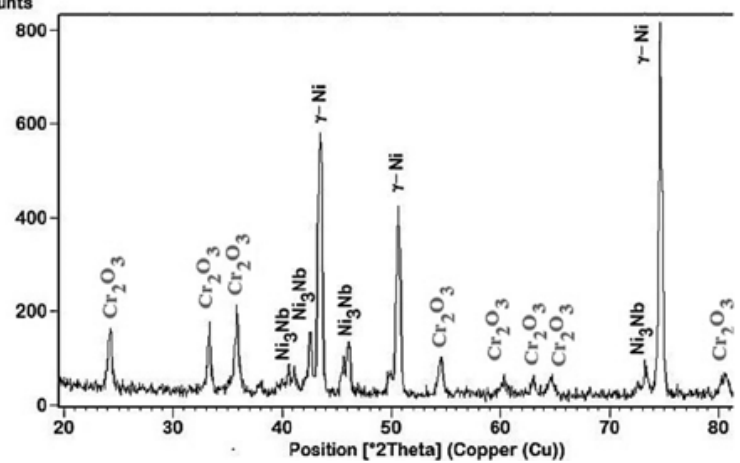

Rys. 5. Wyniki badań produktów korozji rur ożebrowanych ze stopu Inconel 625: a) powierzchnia próbki z warstwą produktów korozji, b) wyniki mikroanalizy składu chemicznego (EDS), Analiza wyników i wnioski c) wyniki analizy składu chemicznego produktów korozji Fig. 5. The results of the finned tubes corrosion products examination of Inconel $625:$ a) the sample surface with a layer of corrosion products $b$ ) the results of chemical composition microanalysis (EDS) Analysis of results and conclusions, c) the results of analysis of chemical composition of the corrosion products

\section{Analiza wyników i wnioski}

Analiza zmiany masy próbek rur ożebrowanych ze stopów niklu spawanych laserowo podczas badań odporności na korozję wysokotemperaturową w symulowanych spalinach wskazuje, że charakteryzują sie one wysoką odpornością na korozję wysokotemperaturową w atmosferze spalin typowych dla układów suchego gaszenia koksu. Przebieg korozji jest zbliżony do funkcji liniowej, tj. wraz z czasem oddziaływania temperatury i gazów korozyjnych wzrasta masa produktów korozji (rys. 2).

Stwierdzono, że szybkość korozji jest podobna dla wszystkich badanych próbek, niezależnie od technologii wykonania połączenia oraz materiału i wynosi średnio ok 0,0002 g/100 h (rys. 2). Liniowy charakter przebiegu procesu korozji oraz określona zależność zmiany grubości żebra w czasie pozwoliły na wyznaczenie trwałości rury ożebrowanej rozumianej jako czas, w którym jest zachowane połączenie metaliczne pomiędzy rurą a żebrem, co zapewnia prawidłową wymianę ciepła [1]. Na podstawie przeprowadzonych pomiarów zmiany szerokości żebra w funkcji czasu stwierdzono, że prawidłowo wykonane złącze rura płaskownik o szerokości $1 \mathrm{~mm}$, w warunkach korozji wysokotemperaturowej w spalinach o składzie chemicznym N2 +9\% $\mathrm{O}_{2}+0,08 \% \mathrm{SO}_{2}+0,2 \% \mathrm{HCl}$ (typowe spaliny dla kotłów odzysknicowych 
w układzie CDQ) charakteryzują się trwałością ponad 10 lat. Każda niezgodność spawalnicza w postaci zaniżonego lica spoiny, braku pełnego przetopienia, pęknięcia, porów i pęcherzy, która skutkuje zmniejszeniem przekroju spoiny, może obniżać trwałość rury ożebrowanej. Podobne badania wykonane dla rur ożebrowanych ze stali konwencjonalnych ferrytyczno-perlitycznych w gatunku P265GH wykazały, że trwałość rur ożebrowanych jest na poziomie 40 miesięcy [1].

Potwierdzają to wyniki badań metalograficznych. Ocena wizualna próbek po badaniach odporności na korozje wysokotemperaturową wykazały na powierzchni wszystkich próbek jednorodną warstwę produktów korozji (rys. 3). Warstwa produktów korozji na powierzchni rury ożebrowanej powoduje nieznaczne ograniczenie wymiany ciepła pomiędzy spalinami a wodą lub parą wodną wewnątrz rury, natomiast zabezpiecza przed korozja wysokotemperaturową. Wyniki mikroanalizy składu chemicznego (EDS) produktów korozji zarówno dla rur ożebrowanych ze stopu Inconel 600 (rys. 4b) jak i dla rur ze stopu Inconel 625 (rys. 5b) potwierdziły większą zawartość chromu oraz tlenu, co wskazuję, że obecność warstwy pasywującej tlenku chromu (rys. 4a, 5a). Analiza wyników analizy fazowej (XRD) badanych produktów korozji wykonana na dyfraktometrze rentgenowskim JEOL JDX-7S, stosując lampę z anodą miedzianą $\left(\lambda_{\text {cuka }}=1,54178 \AA\right.$ Á) zasilaną prądem o natężeniu $20 \mathrm{~mA}$ przy napięciu $40 \mathrm{kV}$, oraz monochromator grafitowy na proszkowych próbkach produktów korozji, potwierdziła obecność tlenku $\mathrm{Cr}_{2} \mathrm{O}_{3}$ w warstwie produktów korozji (rys. 4c, 5c).

Jest to korzystne ze względu na to, że warstwa $\mathrm{Cr}_{2} \mathrm{O}_{3}$ jest ciągła i dobrze przylega do podłoża, a w warunkach korozji wysokotemperaturowej szybko się odbudowuje, co zapewnia stałą ochronę przed korozją. W stopie Inconel 625 ponadto ujawniono również fazę Ni3Nb (rys. 5c). Potwierdzono również tą fazę w strukturze materiału próbek po wytrzymaniu w temperaturze $800^{\circ} \mathrm{C}$ przez 1000 godzin zarówno w materiale rury jak również w materiale żebra. Obecność tej fazy w elementach pracujących w temperaturach powyżej $650^{\circ} \mathrm{C}$ powoduje spadek właściwości wytrzymałościowych [5].

Na podstawie przeprowadzonych badań oraz analizy ich wyników stwierdzono, że:

- rury ożebrowane spawane laserowo ze stopów niklu Inconel 600 i Inconel 625 są odporne na korozję wysokotemperaturową w atmosferze spalin $\left(\mathrm{N}_{2}+9 \% \mathrm{O}_{2}+0,08 \% \mathrm{SO}_{2}+0,2 \% \mathrm{HCl}\right)$ typowych dla instalacji QCD w temperaturze do $800^{\circ} \mathrm{C}$

- korozja wysokotemperaturowa w zakresie do 1000 godzin przebiega liniowo

- z szybkością 0,0002g/1000h, co potwierdza bardzo dużą odporność na korozję chemiczną rur ożebrowanych ze stopów niklu

- na powierzchni tworzy się warstwa pasywująca zbudowana głównie z tlenku chromu $\mathrm{Cr}_{2} \mathrm{O}_{3}$, która zabezpiecza powierzchnię rur ożebrowanych przed oddziaływaniem agresywnego środowiska spalin.

Praca sfinansowana w ramach projektu PBS1/A5/13/2012, pt.: "Technologia spawania laserem rur ożebrowanych ze stali austenitycznych i stopów niklu przeznaczonych do pracy w kotłach o parametrach nadkrytycznych i ultra nadkrytycznych” przez NCBiR

\section{Literatura}

[1] M. Więcek: Wpływ technologii spawania na strukturę i właściwości rur ożebrowanych dla przemysłu energetycznego, rozprawa doktorska, Politechnika Śląska, Wydział Inżynierii Materiałowej i Metalurgii 2015.

[2] T.Chmielniak, H. Łukowicz, A. Kochaniewicz, M. Mroncz, Supercriticalcoal - firedunits. Directions of improving efficiency and reducing $\mathrm{CO}_{2}$, Energetyka, 2011, nr 2-3, s. $84-87$.

[3] Raporty Parlamentu Europejskiego, Energetyka i Środowisko, 10.2010.
[4] P. Adamiec, G. Niewielski, S. Lalik: Badania spawanych rur ożebrowanych po symulowaniu warunków eksploatacji, Materiały konferencyjne: VIII Międzynarodowa Konferencja Spawanie w Energetyce, Tatrzańska Łomnica 1996.

[5] S. Zhang, D. Zhao, Aerospace materials handbook, CRC Press, 2002, ISBN 1439873305 